\title{
Wyrok Sądu Metropolitalnego w Katowicach (c. Sobański) z 29.08.2006 r. z tytułu niezdolności do podjęcia istotnych obowiązków małżeńskich (safizm)
}

Ius Matrimoniale 12 (18), 161-166

2007

Artykuł został opracowany do udostępnienia w internecie przez Muzeum Historii Polski w ramach prac podejmowanych na rzecz zapewnienia otwartego, powszechnego i trwałego dostępu do polskiego dorobku naukowego i kulturalnego. Artykuł jest umieszczony w kolekcji cyfrowej bazhum.muzhp.pl, gromadzącej zawartość polskich czasopism humanistycznych i społecznych.

Tekst jest udostępniony do wykorzystania w ramach dozwolonego użytku. 


\section{Wyrok Sądu Metropolitalnego w Katowicach (c. Sobański) z 29.8.2006 z tytułu niezdolności do podjęcia istotnych obowiązków małżeńskich (safizm)}

\section{Przebieg sprawy:}

ID oraz IR zawarli malżeństwo 30.12 .1989 w kościele Trójcy Świętej w (...). Ważność tego małżeństwa zaskarżyl JD 25.7.1990 w Biskupim Sądzie Duchownym w (...). Po uzupełnieniu skargi sprawa została 15.5.1991 przyjęta do procesu z tytułu niezdolności pozwanej do podjęcia istotnych obowiązków małżeńskich. Wyrokiem z 5.8.1995 Trybunał orzekt, że nie udowodniono nieważności małżeństwa. Wskutek apelacji z 29.8.1995 powoda sprawa znalazła się w Trybunale II instancji, tj. w (...). Trybunał ten orzekł dnia 18.8.2005, że udowodniono nieważność małżeństwa i - tym samym - uchylit wyrok Trybunału I instancji. Na popartą przez Biskupa (...) oraz Oficjata Trybunału II instancji prośbę powoda z 17.9.2005 Najwyższy Trybunal Sygnatury Apostolskiej reskryptem z 18.1.2006 wyznaczył Sąd Metropolitalny w Katowicach do rozpatrzenia sprawy w III instancji. Akta sprawy nadeszły 6.2.2006. Dnia 13.2.2006 wyznaczony został kolegialny skład Sądu. Przedmiotem sprawy jest pytanie, czy udowodniono nieważność małżeństwa $z$ tytułu niezdolności pozwanej do podjęcia istotnych obowiązków małżeńskich, równoznaczne z pytaniem, czy należy zatwierdzić wyrok Trybunału II instancji. Powód nie przedłożył nowych wniosków dowodowych, pozwana nie zareagowała na pisma Sądu. Sąd wyrokując musi przeto oprzeć się na materiale nagromadzonym w I i w II instancji.

\section{Prawny i faktyczny stan sprawy:}

1. Mające w rozpatrywanej sprawie zastosowanie normy prawa wyfożono w wyrokach Trybunałów poprzednich instancji. Słusznie zauważono w wyroku II instancji, że „trudnym zadaniem jest wymienić 
wszystkie istotne obowiązki małżeńskie, których niezdolność wypełnienia powoduje nieważność małżeństwa”. Obowiązki małżeńskie rzeczywiście wymagają zdefiniowania, podobnie jak konieczne jest wykazanie związku przyczynowego między obowiązkiem i czynnikiem uniezdalniającym do jego wypełnienia. Jednak spojrzenie na małżenstwo jako na zespól praw i obowiązków nie powinno przesłaniać faktu, że małżeństwo to ludzka, międzyosobowa „głęboka wspólnota życia i miłości" (konst. Gaudium et spes 48). Obok więc pytania o zdolność do wypełnienia konkretnego obowiązku trzeba postawić pytanie o osobowe zdolności do oddania się drugiej osobie, zaakceptowania jej - o zdolność „wyjścia przed siebie”, do międzyosobowej - mężczyzny i kobiety - jedności. Przez zawarcie małżeństwa tworzy się nowa jedność, w której małżonkowie nie przestają być sobą, nie rezygnują z tego, czym są, ale integrują się w pewną całość obejmującą duchowe i fizyczne aspekty ich życia. W tej jedności miłość małżonków wyraża się, rozwija i dojrzewa (por. konst. Gaudium et spes 50). Ma to być „miłość pelna, to znaczy ta szczególna forma przyjaźni, poprzez którą małżonkowie wielkodusznie dzielą między sobą wszystko, bez niesprawiedliwych wyjątków i egoistycznych rachub" (Paweł VI, enc. Humanae vitae 9). Kłóci się z taką miłością egoizm, szukanie siebie, tendencje do panowania i rządzenia, agresja wobec partnera. W świetle orzecznictwa kościelnego małżeństwo wymaga zdolności do oddania się drugiej osobie zarówno w sferze fizycznej jak i duchowej przy zachowaniu autonomii i godności osób, wymaga zdolności do przezwyciężania własnego egoizmu oraz do dostrzegania własnych niedostatków - do wychodzenia poza swój własny świat. Trzeba podkreślić wyłączność wspólnoty małżeńskiej, co oznacza oddanie się bez reszty i ofiarne współdziałanie dla wspólnego i wzajemnego dobra. Tego wszystkiego małżonkowie mają prawo wzajemnie oczekiwać, wszystko to składa się na małżeństwo i jego kształt prawny.

2. Powód zaskarżając swe małżeństwo powołał się na oświadczenie pozwanej, że „ma zboczenia lesbijskie”. W doprecyzowanej skardze z 24.4.1991 napisał, że żona w trzy miesiące po ślubie wyjaśniła mu, iż „nie czuje pociągu fizycznego" ani do niego ani do innych mężczyzn, oraz że „tylko stosunki cielesne z kobietami dawały przed ślubem i dają obecnie jej satysfakcję", zaś małżeństwo zawiera "tylko i wyłącznie pod presją rodziców i dla swojego bezpieczeństwa życiowego". Konsekwentnie też przyjęto sprawę do procesu ,Z tytułu niezdolności do podjęcia istotnych obowiązków małżeńskich z przyczyn natury psy- 
chicznej po stronie pozwanej niewiasty na skutek obciążenia jej dewiacją seksualną". Pozwana w pismach kierowanych do Sądu I instancji zarzucała powodowi oczernianie jej, utrzymywała, że jest fizycznie i psychicznie zdolna do małżeństwa i wypełnienia związanych $\mathrm{z}$ nim obowiązków, jednak w trakcie procesu w I instancji nie zjawiła się do złożenia zeznań, nie odpowiedziała też na zaproszenie biegłego. Zeznania złożyła pozwana dopiero w Trybunale II instancji. Przyznała, że w okresie przedślubnym przyjaźniła się z kobietą, której pomagała przez trzy lata, a przyjaźn ta była „odbierana negatywnie z tej racji, iż osoba ta nadużywala alkoholu”. Pozwana zeznała: „Pożycie intymne uktadato sie dobrze przez pewien okres, byt to czas okolo jednego miesiqca. W tym czasie dostatam lekarstwa od ginekologa, które mialy w jakimś sensie ograniczyć ból w czasie wspólzycia i przez okoto 10 dni owo wspótzycie nie mogto mieć miejsca". Zeznania te nasuwają wątpliwości: skoro wspólżycie wywoływało ból, trudno twierdzić, że układało się dobrze. Biegly powolany w I instancji stwierdził w konkluzji wydanej na podstawie akt sprawy: „Zachodzi uzasadnione podejrzenie graniczace $z$ pewnościa, iz powódka przejawiata $w$ okresie zawierania matżeństwa $i w$ czasie jego trwania odchylenia $w$ zakresie ukierunkowania popedu ptciowego odpowiadajace rozpoznaniu biseksualizmu z przewaga sklonności homoseksualnych”. W tej sytuacji, ,wobec braku jednoznacznego stwierdzenia przez bieglego psychiatrę-seksuologa obciążenia pozwanej homoseksualizmem, który uniezdalniałby ją do podjęcia obowiązków małżeńskich" Trybunał I instancji orzekł, że nie udowodniono nieważności małżeństwa.

3. W orzecznictwie kościelnym stosuje się w odniesieniu do biseksualizmu te same zasady, które wchodzą w grę przy rozpatrywaniu spraw $\mathrm{z}$ homoseksualizmu, konkretnie: spraw z tytułu niezdolności do podjęcia istotnych obowiązków małżeńskich uzasadnionej homoseksualizmem (sent. c. Erlebach z 29.10.1998 - RRT Dec., 90, 2003, 681). Homoseksualizm postrzega się w orzeczeniach sądów kościelnych jako zaburzenie osobowościowe, kłócące się z naturą oraz przymiotami małżeństwa i - tym samym - uniemożliwiające nawiązanie wspólnoty zorientowanej na dobro małżonków. Trzeba jednak odróżnić „prawdziwy homoseksualizm" jako zaburzenie osobowości od przygodnych kontaktów i przelotnych znajomości homoseksualnych, czyli homoseksualizm „konstytucjonalny” i „okazjonalny". Kryterium rozróżnienia stanowi nie sama częstotliwość kontaktów, lecz to, czy skłonność ku osobom tej samej płci jest do opanowania (R. Sobański, w: Ius Matri- 
moniale 2, 1997, 234). Trzeba przy tym pamiętać, że wylączność wzajemnego oddania się małżonków obejmuje sferę duchową i fizyczną. „Ptciowość, poprzez która mężczyzna i kobieta oddaja się sobie we wtasciwych $i$ wytacznych aktach matżenskich, nie jest bynajmniej zjawiskiem często biologicznym, lecz dotyczy samej wewnętrznej istoty osoby ludzkiej jako takiej. Urzeczywistnia się ona w sposób prawdziwie ludzki tylko wtedy, gdy stanowi integralna część mitości, która mężczyzna i kobieta wiaża się z soba az do śmierci. Catkowity dar z ciata bytby zaktamaniem, jeśliby nie byt znakiem i owocem petnego oddania osobowego..." (Jan Paweł II, enc. Familiaris consortio, 11). Stąd spowodowana homoseksualizmem (czy biseksualizmem) niezdolność do podjęcia istotnych obowiązków małżeńskich zachodzi nie tylko wtedy, gdy dana osoba nie jest zdolna do rezygnacji z pozamałżeńskich kontaktów płciowych (a tym samym jest niezdolna do dochowania wierności malżeńskiej), lecz także wtedy, gdy skłonności homoseksualne stoją na zawadzie duchowej, osobowej integracji w związku mężczyzny i kobiety.

4. Z orzeczeniem Trybunału I instancji stwierdzającym, że brak wystarczających dowodów na „obciążenie pozwanej homoseksualizmem, który uniezdalniałyby ją do wypełniania obowiązków małżeńskich", trzeba się zgodzić, gdy chodzi o niezdolność do pożycia wyłącznie heteroseksualnego. Pośrednie dowody na kontakty lesbijskie (list do przyjaciólki pisany w dwa dni po sporządzeniu protokołu przedślubnego, zeznania świadka w II Instancji) nie dają wystarczających podstaw do twierdzenia, że ów popęd fizyczny był nie do opanowania. Nasuwają się jednak poważne wątpliwości odnośnie do zdolności pozwanej do duchowej, osobowej integracji z partnerem. Biegły powołany w II instancji, nie będąc przekonany o zaburzeniach safistycznych pozwanej, poddał analizie rysującą się w aktach sprawy sylwetkę jej osobowości. Pisze on: „Dominanta w sylwetce osobowości p. ID wydaja się być następujace cechy: obnizona wrażliwość uczuciowa na stany potrzeb innych, niski poziom odpowiedzialności, obniżona zdolność do wytrwatości i angażowania sie $w$ dziatania dlugotrwate wymagajace wtasnego wysitku oraz realizacji wartości ponadosobistych, sktonność do manipulowania innymi dla uzyskania własnych korzyści...". Opinię swą wyraża biegły w formie hipotetycznej, wskazując na ,tendencję do podejmowania działań przynoszących bezpośrednią i natychmiastową gratyfikację potrzeb", „skłonności do poszukiwania zmienności, rozmaitości doznań oraz swego rodzaju bezceremonialność w zachowaniu”. Osobowości takiej brak ,przystosowania do podejmowania zadań wyznaczanych na 
kolejnych etapach życia psychicznego”. Wedle biegłego, „późniejsze tłumaczenia, iż kontakty psychiczne nie spełniły jej oczekiwań i były czymś bolesnym, mogą stanowić formę racjonalizacji, sposobu tłumaczenia niechęci w stosunku do męża”. Przypuszczalnie „niechęć tego typu była powodowana albo brakiem dyspozycji do wspólprzeżywania z drugą osobą aktu miłości albo brakiem doznań zmysłowych odpowiadających jej strukturze psychicznej". Biegły wyraził swą opinię w formie hipotetycznej - nie mógł inaczej, skoro pozwana nie zjawiła się do badania. W aktach sprawy Sąd znajduje jednak wystarczające argumenty każące uznać opinię biegłego za uzasadnioną.

5. Bezsporne jest, że pożycie intymne układało się dobrze najwyżej przez miesiąc (tak twierdzi pozwana). Przyczyną niedobrego „układania się" byla według pozwanej brutalność powoda. Brak jednak podstaw do przyjęcia, by powód był brutalem. Pozwana w piśmie z 2.9.1991 tłumaczy, że chciała „otrzymać niewiele, trochę ciepła, miłości, uczucia i zrozumienia". A przecież zeznaje, że malżeństwo zostało zawarte z milości - nie widać przyczyn, dla których powód miałby w ciągu miesiąca po ślubie przemienić się w ordynusa. Trudno nie przyznać racji biegłemu piszącemu o próbach pozwanej racjonalizacji własnych zachowań, przy czym oceniając wypowiedzi pozwanej trzeba zwrócić uwagę na jej wieloletnie obiecywanie i ociąganie się ze złożeniem zeznań - pozwana sama podważa swą wiarygodność.

Ważnym ogniwem w łańcuchu dowodów i poszlak jest list pozwanej z 13.7.1990 do jednej ze świadków, do której córki - jak zeznała świadek - ,stosunek pozwanej był nienaturalny”. Pozwana opisuje w liście swą wizytę u lekarza-specjalisty. Pisze, że po raz pierwszy mogła „mówić komuś o swoich problemach w sposób zupełnie naturalny", że usłyszała, iż „nie jest chora ani zboczona, lecz było to uczucie, którego ona i przyjaciółka potrzebowały”; że dowiedziała się, iż ,podłoże tych uczuć jest u każdej z nich inne"; że wychodząc za mąż nie darzyła powoda miłością, małżeństwo było koszmarem, a ona miała „tė̇ dużo winy". Pozwana nie zakwestionowała autentyczności tego listu, zaprzeczyła, by między nią i K. miały miejsce intymności czy seks: „byly rozmowy, jak sie zachować, jak być czlowiekiem wolnym, móc rozwijać swoje zainteresowania. Potrafityśmy godzinami rozmawiać, czytać ksiąz$k i$, dyskutować. Znamienne jest, że właśnie takich rozmów nie prowadzono w malżeństwie stron. Przy czym przyczyny tego stanu jasno wskazała sama pozwana w tymże liście: wyszla zamąż nie darząc powoda uczuciem, adresatkami jej uczuć byly kobiety. Małżeństwo stron od 
początku nie tworzylo wspólnoty duchowej, a nie będąc nią zawiodło też jako wspólnota fizyczna.

6. Rysujący się w aktach obraz sprawy pozwala Sądowi osiągnąć moralną pewność, że pozwana z racji swej struktury psychicznej nie byla zdolna podjąć istotnych obowiązków małżeńskich. Nie ulega wątpliwości, że pozwana jest zdolna do fizycznego współżycia heteroseksualnego, nie zdołano wyjaśnić, czy homoseksualizm jest u pozwanej dominujący, ani czy jest zdolna do dochowania fizycznej wierności. Wykazano natomiast niezdolność psychiczną pozwanej do trwania we „wspólnocie calego życia” (por. k. 1055 §1), powstającej przez akt woli, „,w którym mężczyzna i kobieta w nieodwołalnym przymierzu wzajemnie się sobie oddają i przyjmują w celu stworzenia małżeństwa" (k. 1057 §2). Takie nieodwolalne i wyłączne oddanie się i przyjęcie przerastało możliwości pozwanej, niezależnie od tego, czy ona miala wolę takiego przyjęcia i oddania się.

Wobec takiego stanu sprawy Sąd Metropolitalny odpowiada twierdząco na pytanie procesowe i orzeka, że udowodniono nieważność małżeństwa. Tym samym Sąd zatwierdza wyrok Trybunału II instancji.

Wyrok podlega wykonaniu. Pozwana nie może zawrzeć nowego małżeństwa bez uprzedniej zgody - po zasięgnięciu opinii biegłego właściwego Ordynariusza miejsca. 